\title{
Market Model with Positive Demand Curve Overthrows Marxist and Keynesian Model
}

\author{
Alqi Naqellari \\ Mediterranean University of Albania, Albania
}

Doi: 10.36941/ajis-2020-0042

\begin{abstract}
In this paper is analyzed the demand and supply side from the perspective of Marxist theory. The supply and demand side is both analyzed with their respective characteristics in capitalism, socialism and in a mixed economy. The possibilities of a macroeconomic equilibrium by considering the following concepts such as commodity, value, price, profit are analyzed. The aim of this paper is: to develop through a non-exhaustive analysis, the common features and differences between macroeconomic models of the aggregate market in the two systems, to build the aggregate market of a macroeconomic model by taking into account these characteristics and to emphasize its importance for the economy. In conclusion, differences between concepts related to macroeconomic equilibrium were identified. A new equilibrium model for the socialist and capitalist model was built. In centralized economies, demand and supply curve lies in a parallel curve with the X-axis, were domestic product is placed. In the market economy model, the demand and supply curve has a positive slope and stretch simultaneously over the market price line. They do not intersect with each other as in the Classical and Keynesian model. This market model applies to the economy. It allows governments, central banks, research institutions, universities, various researchers, etc. to analyze macroeconomic indicators. In this paper, the model is applied to the Albanian economy. In this paper, we used the methods of analysis and synthesis, comparison and description, the method of creating virtual market models, etc.
\end{abstract}

Keywords: demand, supply, equilibrium, fundamental socialist law, profit, the value of commodities, abstract and concrete labor, use-value and value of goods, commodity

\section{Introduction}

The current analysis of macroeconomic market models have skipped Marxist theory on the market and are focused mainly on classical, neoclassical, Keynesian, neo-Keynesian theory. Leaving aside the Marxist theory of the dynamics of economic systems, property, market, capital, goods, labor, distribution, etc., came as a result of the failure of the socialist system in all the Eastern European socialist countries. The failure of socialism in the Soviet Union and other countries, including the former People's Socialist Republic of Albania, was a waste for Marxist theory because it created a gap in international economic thinking. The socialist system was anathematized, as anti-human, conservative, confined and defeated. This hit of the socialist system had its reasons because, in many of the countries that applied it, it became a despotic, anti-populist system, dominated by the individual's cult, corruption, class struggle, isolation from the world, limit of the free market initiative, lack of market, lack of private property, etc. Failure of these countries to adapt to the newly created conditions and with the external economic and political environment caused the failure of 
the system.

In countries that applied Marxist theory in their economies happened otherwise. We can mention here China and Vietnam that still today develop successfully Marxist theory in their countries' economic conditions. Marxist Thought, both theoretically and practically, still exists in China in "China's Socialist Market Economy" and in "Socialism with Chinese characteristics". China under the leadership of the non-dogmatic Marxist theory, "Marxism in the Chinese context" elaborated in terms of "market economy", from the size of GDP ranks in the second position after the US and soon intends to rank into the first place.

If other ex-socialist countries would have adapted their socialism to the market, it is not known how if the weight will tilt on socialism, capitalism, or a mixed economy, with features of socialism and capitalism. Therefore, it is important to study Marxist theory, to give its role and place in international economic thinking.

It is important to analyze capitalism and socialism under the Marxist point of view because we find elements that enable us to build a new model of macroeconomic equilibrium for the market economy system.

Today, Macroeconomics, in almost all of the Universities of the world, analyses the macroeconomic equilibrium of the market through the supply-demand curves and the respective model. This model is based on Adam Smith's classical theory and John M. Keynes Keynesian theory.

The Aggregate Supply Curve is built by Classics and Keynesians. The classics build a fully inelastic aggregate demand curve, while the Keynesians build it completely elastic. Between Keynesians and Classics is an intermediate space. The Classics and the Keynesians take the Aggregate Demand Curve with a negative slope. There are three arguments for its negative slope, called effects: the real balance, the interest rate effect and the foreign trade effect. By taking the demand curve with a negative slope and the supply curve in both variants, elastic and inelastic, are created two theories with different views on the government role in the economy.

In the Classical case, where the Supply Curve is completely inelastic, government intervention in the market is ignored, meaning that government intervention in the market has no effect on the size of the product, but affects only the price. In the Keynesian case, where the Supply Curve is completely elastic, government intervention in the market is fully efficient, meaning that it affects GDP growth and does not affect price increases. In the intermediate case, an increase in government spending affects both at the same time, GDP grows and prices increase. Building such a model (Fig.1) justifies government expenditure and makes no distinction between consumption, investments and government spending. All these expenditures, according to this theory have an impact on GDP. This means that an increase in government expenditures will boost the economy. An increase of government expenditure, where an "autonomous" term is used, multiplied by the multiplier increases GDP, just as the increase of autonomous C, I and NX.

In reality, this is not the case, government expenditures are not directly linked to investments, they are classified into different groups, where only a small part affects the growth of the economy. It cannot be said that autonomous consumption expenditures included in government expenditures increase GDP. If this would be true then the government would increase only the number of employees in public administration and the consumption will increase, it would be enough to increase borrowing to boost the economy. According to this theory, an increase in consumption would grow the GDP. This is an absurdity and is argued through this equilibrium post-Keynesian model. It is used "post-Keynesian" term because the classics, Smith, Ricardo and Keynes have not built any macroeconomic equilibrium model. Keynes has operated only with formulas and has not made any graphics or equilibrium model. The macroeconomic equilibrium model has been built by economists who came after Keynes. These economists built the figure of the model that we have today in every text of the economy. A typical model is presented in Fig. No.1. 


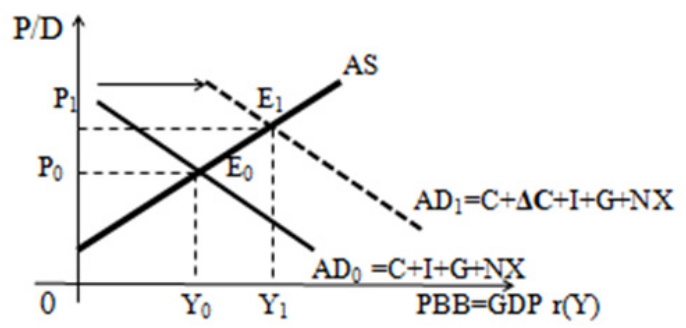

Fig. No.1: Aggregate Market (Is presented the intermediate part of the curve)

Source: Author

$\mathrm{P} / \mathrm{D}$ is the price deflator, placed on the $\mathrm{Y}$ - axis. $\mathrm{PBB}=\mathrm{GDP}(\mathrm{Y})$ is the Real Gross Domestic Product which is placed on the $\mathrm{X}$-axis. Aggregate Demand is marked as (AD) and Aggregate Supply is marked as (AS). Consumption expenditures are marked as (C), gross business expenses are recorded as (I), G are government expenditures minus transfers and interest payments and with (NX) is marked net exports. Initially, according to this model, the equilibrium is at point $E_{0}$, with $Y_{o}$ and $P_{0}$. An increase in $(C)$ shifts $A D$ to the right with $\triangle C$. According to this model, (C) growth has this effect. The transmission effect is $\uparrow \mathrm{C} \rightarrow \uparrow \mathrm{AD} \rightarrow \uparrow \mathrm{PBB}=\mathrm{GDP}$.

This model is inapplicable. We have not read any studies inside or outside of Albania that are based on this model.

In this paper is made the analyses of the demand-supply side and the macroeconomic equilibrium in the socialist system until the 1990s. The supply-demand was derived from the features of the socialist economy. The Original Model of Demand-Supply was built.

It has been analyzed the relationship between private property and the dynamic of the production of goods, (without claiming that this problem is exhausted) according to the Marxist concept, the concepts of goods and their value are given. A demand-supply model was built according to the features of the capitalist system.

The hybrid model of Chinese socialism has also been briefly analyzed. Considerations and features of this economic model have been given.

In the end, the author proposes a New Macroeconomic Market Model. The features of this model are: The aggregate demand curve has a positive slope. Aggregate demand and supply lay both into one line over the price. They are constantly facing the same price, but that does not mean they are in equilibrium. They are far apart and act with each other and over the price. In this way, by their action an equilibrium curve is created, which is expressed simultaneously through income, production, and expenditures.

This model is applicable in practice with the data of every economy.

\section{The Marxist Theory of Supply-Demand and the Factors Related to the Macroeconomic Equilibrium in the Capitalist System}

\subsection{Some market considerations}

In the 1776-1936s, some economic theories have ruled. We mention here two of them, the classical theory with representatives A. Smith and D. Ricardo, and the Marxist theory with representatives K. Marx and F. Engels. The Marxist theory became dominant in Eastern Europe from the '2os to the '9os, for about 70 years. This theory failed and the countries that applied it changed their system and passed from the centralized system into the market system. This theory, in terms of their system, is successfully applied by China and Vietnam, Cuba, North Korea, and so on. One of the dominant economic theories today is Keynesian theory. In the 1930 s this theory prevailed. This theory and the 
Neo-Keynesian theory are studied today in all Macroeconomic or Economics textbooks.

Today, Marxist theory is studied a bit in universities. It is generally avoided, despite being applied very successfully in China.

In this paper, we will analyze the attitude of Marxist theory on demand and supply in the market economy and socialism. The reason we are doing this is that the Marxist theory has not been wrong at all but there have been historical achievements in defining key economic concepts such as commodities, rent, value, etc. Exactly for its value, we have judged it as necessary and indispensable to be analyzed in the market economy and socialism. Including these concepts in our analysis is possible to create a new model of the aggregate market, different from the models that exist today in economics textbooks all over the world. Through this model is possible to have a realistic analysis of the aggregate market. There are brought out different conclusions from those that exist in today's models.

The main representatives of this theory were Karl Marx and Frederick Engels. From Marx, it was called the Marxist theory. Marx analyzed the features of the capitalist system, capital, commodity, market, rent, class struggle, etc. In Marxist theory, these concepts have been analyzed from goods and types of labor that are consumed for its production. They see the balance in the contradictions between concrete and abstract labor, value, and use-value. The contradictions between them are antagonistic in the capitalist system, while they are not antagonistic in the communist (socialist) system. In the capitalist system, the market due to the internal contradictions of commodities cannot come into a balance, except for any spontaneous case. It can only be balanced through the planning process.

Marx argues that the capitalist system, as a result of internal antagonistic contradictions, will be replaced by the communist system. According to the representatives of this theory, in capitalism: 'Each one produces for its own account ... No one knows what amount of the produced product will come out on the market and what amount of product can find consumers ... and generally whether it will be sold or not. In social production anarchy prevails "(Engels F. 1974). The concept of anarchy is related with the unplanned development of production and circulation of goods, their development not according to the needs of the economy and employees, but according to the interest of private owners of the means of production to generate the highest profit (Political Economy, Capitalism 1985). 'In market conditions, the fate of manufactured goods and their producers depends on the market. Everything presented as a commodity is produced to be exchanged. In capitalism, commodity exchange "is the simplest, most common, most prevalent report ... we see every day". (Lenin, I.V.1970).

Thus the capitalist form of the working process ... 'shows two characteristic phenomena. First, the employee works under the control of the capitalist to whom the work belongs... Second; the product is the property of the capitalist and not of the employee, his immediate producer. (Marx K. 1968).

According to Marx, 'capitalist production is not determined by the dependence of social production on social needs, although this is expressed in the limited form of effective demand 'in the market so that the capitalist does not meet the social need but expands the capital' ... The distinctive characteristic of goods production is that they are not produced directly for social needs but are produced for sale, to earn money. Things are not produced as use-value but as value' (Clarke S. 1995). According to Stalin, 'the features and main requirements of the fundamental economic law of today's capitalism could be formulated roughly so; securing maximum capitalist profit by exploiting, abolishing, and impoverishing the majority of the country's population through the enslavement and systematic robbery of the peoples of other countries, especially the backward countries, finally by wars and the militarization of the national economy, which are used to secure greater profits' (Stalin J.1974).

Engels supported Marx's theory, Engels. He argued that 'the immediate consequence of private property is trade', which is immediately and necessarily antagonistic, based on 'diametrically opposed interests' and giving rise to 'mutual mistrust'. (Clarke S. 1995) 
Through the above quotations, the fundamental law of capitalism, formulated by Marx, and market analysis, is emphasized that the internal contradictions of the capitalist system are expressed in the market. Their classes with the antagonistic interests that represent this system, capitalists and proletarians, are crashed with each other. The market, in capitalism, raises the contradiction between labor and capital. The discrepancy between demand and supply is seen as legitimate in this system.

\section{2}

The concept of commodity and its value

A commodity is considered to be the basic cell of the capitalist economy that contains the main distinctive features and contradictions of the capitalist system.

The commodity is a product that is produced to be sold in the market. It contains use-value and value. The use-value has a social character. Because of its features, it meets certain human needs, for food, for clothing, for living, etc. Footwear, for example, has value to use because they are used to go on foot, protect the feet and keep them warm. Or a jacket serves to wear it, to protect the body from the cold. The use-value completes not only the needs of the owner but the needs of the entire society.

The value of the use of goods gains this quality as social property when goods are worth because not all goods have value. Air, water resources, fruits in the forest has no social use-value because it is not spent concrete work on them, so they have no materialized value. Shoes and jackets have value, they have a cost, they have price, because they are made by a shoemaker and a tailor, and here is the concrete work, the value of the use, the value of the goods.

The labor that is spent on the production of certain goods, with certain qualities for fulfilling a certain need is called concrete labor. 'Exchange value, at first sight, presents itself as a quantitative relation, as the proportion in which values in use of one sort are exchanged for those of another sort, a relation constantly changing with time and place.' (Marx K. 1968). So a person who does and adjusts the pants makes a concrete job, he is a tailor. A person who makes and adjusts shoes is called a shoemaker. In this way, concrete labor gives the value of the use of the goods.

Besides this work for the production of goods, is also needed what is called abstract labor. Thus, the use-value is shown by the value. The value turns a product with use-value in a commodity. The value of the good does not appear in the features that the good has. For this, Marx emphasizes: "On the one hand all labor is the expenditure of human labor power, and in its character of identical abstract human labor, it creates and forms the value of commodities. On the other hand, all labor is the expenditure of human labor power in a special form and with a definite aim, and in this, its character of concrete useful labor; it produces use-values "(Marx K. 1968)

The value appears in the exchange process. Value is the common thing that goods have because the use-value may be different, the value makes them comparable. Human power is consumed for the manufacture of goods, and this is exactly what gives value to the goods. Exactly, the value represents the value of social labor that is spent on producing use-value.

Labor that appears to be a waste of social work in general, regardless of concrete labor and from the product that it produced, is abstract. Thus, the value of the goods corresponds to the abstract labor which makes the commodity interchangeable, while concrete labor makes it useful because of its features.

'Use-value realizes itself only in use or in consumption... use-value is direct materials, where a given economic ratio is expressed, the exchange-value' (Marx K.1977). Labor that creates exchange value is general abstract labor (Marx K.1977). 'As exchange-values, all commodities are 'time of labor'. (Marx K. 1977) 'the work that creates exchange value is social labor' or ' general human labor '...' the commodity is a unity of the exchange-value and use-value'... The exchange value of each commodity is expressed in the use-value of any other commodity' (Marx K.1977)

"As crystals of this social substance, common to them all, they are - Values."(Marx K. I 1968) Value expresses economic relations between the producers of goods that appear in the production process.

The value of the goods is measured by the amount of labor that is spent on the production of 
the goods; the amount of labor is measured by working time, hours, days of the month, etc. So the greater the time it takes to produce a product, the more value it has. The working time spent by different manufacturers for the production of a unit of the good is called the individual working time. According to Marxists, the value of goods is determined by the "socially necessary labor" (Political Economy, Capitalism 1985). This is considered to be so in the average social production conditions. As averages time it is considered the time spent by manufacturers that have the largest share in the market. According to Marx, the magnitude of the value of a commodity is "proportional to the quantity and not proportional to the productive power of labor that is carried on it" (Marx K.1968).

In the private economy, the producer does not know exactly how much are the needs $\mathrm{ff}$ his goods and who will be the buyers that will buy his goods, so it appears as private work, as private work for each producer that produces a certain commodity. But this individual work also appears as social work because it is also realized by including the constant capital that represents the work of other enterprises. In this way, the private character of labor appears in the production process, through concrete labor, the social character appears in the market when goods are exchanged with each other. In the market comes out whether the labor of a producer is useful or not.

Here appears the contradiction between the private and social character of labor which is the fundamental contradiction of the production of goods. This raises the contradiction between the value and the use-value, which turn contradicts between concrete labor and abstract labor. In terms of these contradictions, the fate of goods and producers depends on the market, where their production and exchange are adjusted by the law of value. In this way, the price of the commodity must have in principle the value and the value must have the socially necessary labor for its production.

The market price mechanism is that makes possible the realization of the law of value. In the market, the price does not match the value, they fluctuate continuously. This fluctuation that has two variables: price and value, represents the ratio between demand and supply.

What is the role of price in setting equilibrium according to Marxists? ... 'If you think that the value of labor or other goods is ultimately determined by supply and demand, you are severely wrong. Supply and demand regulate temporary market price fluctuations. They can explain why the price of a commodity on the market rises above or falls below its value, but they cannot explain this value at all'. Suppose the demand and supply cover each other. 'It is exactly in that moment when these opposing forces become equal, they paralyze one another and stop acting as in one and the other direction. At the moment when is established the equilibrium between demand and supply, they stop acting, the price of a commodity in the market coincides with its true value, at the normal price, around which its market prices go around. Therefore, when we study the nature of this value, we do not take into account the temporary actions of supply and demand on market prices. This also counts for the prices of all other commodities". (Marx, K. \& Engels F. 1958)

By what is the price of a commodity determined?

The Marxist theory states: 'From the competition between buyers and sellers, the relationship between demand and supply, between the need and the number of goods that are needed to fill it. The competition that determines the price of goods has three sides ... '... there is a competition between sellers, which reduces the price of the goods they offer. But there is also competition among buyers, which, in turn, raises the prices of the goods offered. Finally, there is a competition between the buyers and the sellers: these wish to purchase as cheaply as possible, those to sell as expensive as possible. The result of this competition between buyers and sellers will depend upon the relations between the two above-mentioned camps of competitors, namely where the competition is stronger, on the side of buyers or the side of sellers. '(Marx K \& Engels F, 1958).

'If then, the supply of a commodity is less than the demand for it, competition among the sellers is very slight, or there may be none at all among them. In the same proportion in which this competition decreases, the competition among the buyers' increases. Result: a more or less considerable rise in the prices of commodities.'.... 'What is a rise, and what a fall of prices? What is high and what a low price? If the price is determined by the relation of supply and demand, by what 
is the relation of supply and demand determined?' (Marx K. \& Engels F, 1958)

"The changing relation between supply and demand causes a rise or a fall of prices, consequently:

A mass of capital will be thrown into the prosperous branch of industry, and this immigration of capital into the provinces of the favored industry will continue until it yields no more than the customary profits, or, rather until the price of its products, owning to overproduction, sinks below the cost of production." (Marx K. \& Engels F, 1958). The opposite happens if the price of a commodity falls below its cost of production, then capital will be withdrawn from the production ... 'that is, until the commodity price rises again to the level of its cost of production, because the current price of a commodity is always either above or below its cost of production'(Marx K \& Engels F, 1958). In this way, capital steadily passes from one branch to another.

\subsection{Market equilibrium and Demand - Supply}

The Marxist theory of demand and supply does not give any detailed definition. Demand and supply are treated with the concept of enterprise or branch, with the concept of microeconomics, rather than of the entire economy, as aggregate demand. Mostly, here are analyzed the problems of the contradictions in the commodity and the problems of market equilibrium.

Marxist theory defined the demand as 'the number of commodities that buyers need', so the number of goods was expressed in units rather than in money.

The supply was understood as "the number of commodities that sellers layout in the market". The goods are expressed in units rather than money, too. Thus, the demand and the supply for a given enterprise are expressed on one hand in units and on the other hand in the price of this commodity compared with its value. In the Marxist theory is explained the essence and the effects of the law of value. It is analyzed regard price formation and the demand and supply equilibrium.

Marxists treat it in two aspects (according to the author). The first aspect is the valuation of the commodity through income and expenses. By treating expenditures as demand and income as a supply, under this law, in the whole of the economy, they are equal. In the second aspect, they are treated as different entities that do not match with each other, in the system where private property rules, where the purpose of production is the profit. They coincide or equate in the socialist system, where social property rules, where the goal of production is to meet the needs of employees and not the profit. In this aspect, if we draw a curve, this would be the equilibrium curve that simultaneously expresses demand and supply.

The law of value in the capitalist economy, in general, is expressed in the fact that 'in the totality of the economy, the amount of commodity prices is equal to the sum of their values' (Political Economy Capitalism 1985).

'The sum of the values of all commodities of an enterprise matches with the number of commodity prices, but in special enterprises and branches of production, the commodities under the influence of competition are sold not with their values but with the prices of production, which are equal to the capital spent plus the average profit '... The fact of price avoidance from value is well explained by Marx based on the law of value, because "the sum of values of all commodities matches the sum of prices". (Marx K. 1975). This means according to the author, that the commodities are realized only in the final act when they pass into the hands of the consumer, and therefore the supply and the demand are equal or express the same, the demand is a realized supply. This is also expressed in the analysis that Marxists make between consumption and production.

Marxist theory links consumption with production and vice versa, where one cannot be understood without the other. Consumption as an expense is the realization of the product, the product only when consumed turns into a product, in a commodity.

'Production is also consumption' ... 'Consumption is also production,' ... 'Production is, therefore, consumption, and consumption is production. Everyone is directly their opposite. '...' Without production, there is no consumption and without consumption, there is no production. 
Consumption generates output in two directions. 1) Only in consumption product is a product '...' Thus the product, differently forms a simple object of nature, is affirmed as such, and becomes product only in consumption '. For example, a costume becomes a costume only when it is worn. 2) Consumption creates the need for new production, therefore, creates the ideal motive of production that is its internal push and its preliminary condition'...' Without need, there is no production. But precisely consumption, consumption is the one that reproduces the need '(Marx K. 1977).

According to Marx, production creates the customer himself. 'Not only consumer goods, but also the way of consumption is created by production, not just objectively, but also subjectively. Thus production creates the customer '. ... 'Production produces consumption; 1) by creating the material for it, 2) by determining the manner of consumption, 3) by promoting to the consumer the need, whose object is the product, he creates. "(Marx K. 1977) 'Production is not just consumption, while consumption is direct production ... Each of them is not only the other and not only intermediates the other but each of them creates the other, creates itself as another. 'Due to consumption, 'the product becomes a product and by the act 'the producer becomes a producer'(Marx K. 1977).

In capitalism, according to Marxists, demand and supply are not equaled by spontaneous production; they can be equalized only in a system where private property does not rule, which has the basis of meeting demand or needs in a planned manner.

The development of capitalist production is subject neither to the needs of the associated producers, nor to the needs of the latter as consumers, but the contradictory logic of the production and accumulation of surplus-value. (Clarke S. 1995). According to Engels, the private property creates a society based on classes with antagonistic interests. This situation determines a permanent disequilibrium between demand and supply., Engels motivates the disequilibrium between demand and supply with the impossibility of the adjustment process, with the ongoing tendencies towards overproduction, with the occasional crises it causes, and so on.

Marxist theory the discrepancy of demand with supply, due to production in private property conditions, because of the antagonistic contradictions between concrete labor and abstract labor, between value and use-value, is seen as a law of the capitalist system. This discrepancy leads to production crises, social shocks, which are eliminated through the revolution.

In capitalism, Marxists cannot establish an equilibrium between demand and supply.

'Private property not only creates society based on antagonism of interest but also sets a permanent disequilibrium between demand and supply. Engels's initial explanation for this disequilibrium and for the crises that it causes is in the aspect of the instability of the adjustment process that comes from ignoring economic actors'. 'The supply is either too big or too small, never corresponds to the demand; because in this unconscious state of humanity nobody knows how great the supply or the demand is. If the demand is greater than the supply, the price increases and, as a result, the supply is to a certain position to be stimulated. As soon as it comes into the market, prices fall; and if it gets bigger than the demand, then falling prices are so important that demand is stimulated once again. So endlessly - a permanent ill state - a permanent change of over-stimulation and flags that prevent everyone from moving forward - a state of constant fluctuation without ever achieving its purpose. (Clarke S. 1995). 'The constant tendency towards equilibrium, in different production spheres, is only practiced in the form of a reaction against the constant shock of this equilibrium' (Clarke S. 1995) ... 'the coordination of supply and demand depends on 'fate', since " Everything is done blindly, as guess-work, more or less at the mercy of accident.' (Clarke S. 1995). Marx notes that "demand and supply are just in equilibrium" sporadically, by chance, "so it is just as a constant law that is not in equilibrium." True movement is one of the fluctuations and disproportion, but 'this real move, where this law is only an abstract, casual and biased factor, has been made by the last political economy into something random and inevitable'. (Clarke S. 1995).

The discrepancy between demand and supply is considered by Marxists as legitimate in the capitalist system: Marxist theory claims that if production is planned production crises disappear, the consequences of market competition are eliminated.

The Marxist theory asserts that the law of discrepancy of demand with the supply leads to 
revolutions.

In Marxist theory when talking about consumption, it is emphasized: 'Insufficient consumption constitutes a permanent historical phenomenon over thousands of years... '. 'Insufficient consumption is, therefore, one of the preliminary causes of the crisis and plays a role that has long been recognized; but he gives us just as little knowledge of the causes of the crises that exist today, as well as of the fact that they did not exist before.' '...crises are unavoidable, and that comes from the capitalist way of production ... are crises of this way of production, as ordering tools of the social revolution' (Engels F.1974.).

Starting from the Marxist theory for the market, from the basic contradictions of production, between the private and social character of labor, from the fundamental contradictions of the capitalist system, between the private character of the acquisition and the social character of production, is build the scheme of fulfilling the demand of the fundamental law of capitalism, the law of profit.

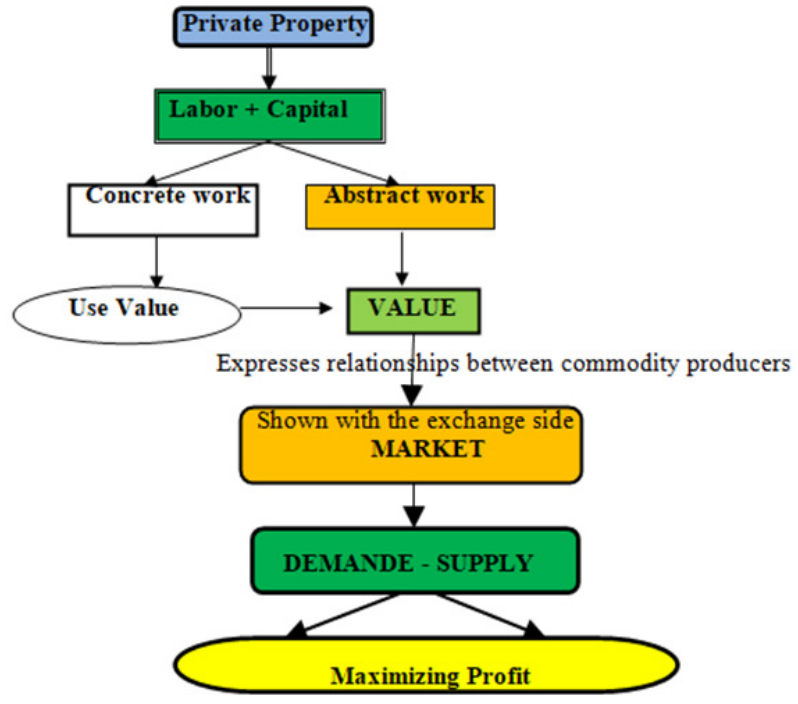

Fig. No.2: The Way of Creating Demand and Supply in Capitalism

Source: Author

According to the above scheme in Marxist theory, there is no model set for the aggregate market, in the capitalist system. There are only analyses, individual demand concepts, and individual supplies, while the Marxist concept has not been properly extended to society in general. Marxist Thought is mainly from the microeconomic point of view, in the analysis of certain commodities or of a particular industry, without going into aggregate demand and supply. In this way, through their theory, we cannot formulate an aggregate market structure.

\section{Marxist View of the Demand-Supply, and for Other Concepts Related to the Macroeconomic Equilibrium in the Socialist System}

\subsection{The concept State-Part in socialism}

What does the Marxist theory of the Communist (Socialist) system say? In this section, we will give only a few statements from K. Marx and F. Engels, as the main representatives of this theory. Marx in 
the "Poverty of Philosophy" states: 'In a future society where class antagonism will disappear, where there will be no more classes, consumption will no longer be determined by the minimum of production time necessary; on the contrary, the amount of time that will be devoted to the production of this or that item will be determined by the degree of social benefit of this item '. (Marx K. 1978.).

For the socialist system and its fundamental law, Engels emphasizes: "When today's productive forces are handled by their ultimately known nature, social anarchy in production will be replaced by planned social production regulation in line with needs both of society as a whole and each of its members alone. Then the capitalist mode of adaptation... will be replaced by a new way of embracing, based on the very nature of today's means of production; on the one hand, with the direct social adaptation of products as tools to keep up and enlarge the production, on the other hand - by their direct personal use as a means of life and enjoyment. "(Marx K. 1978) "The proletariat takes over state power and transforms the means of production, first of all, into state property".

Continuing to explain the consequences of the engagement of the means of production Engels emphasizes: "The opportunity to provide all the members of the society utilizing social production, not only material conditions of existence quite sufficient and continuous improvement day by day but also a development and use altogether free of their physical and mental abilities, '... With the society taking the means of production under its possession, the production of goods will disappear, and with it the dominion of the product over the producers. Anarchy in social production is replaced by a conscious plan organization. 'From now on, social production is possible according to a prearranged plan'. (Marx K. 1978)

Engels when talking about the importance of the value of the goods, for the prize emphasizes that his recognition is also necessary for the socialist society. "It is self-evident that even in this case the society needs to know how much work it takes for the production of any consumer item. It will have to adjust its production plan according to the means of production, which specifically include the workforce. This plan will ultimately be determined by the beneficial effects of various consumer items, weighed and compared to each other and with the amount of work necessary for their production. Then people will do all this in a very simple way, without asking for the help of the famous "worth". (Marx K. 1978).

"If the producers as such knew how much consumers wanted, if they would organize the production, if they were to distribute it all by their selves, then the competition fluctuations and its crisis tendencies would be impossible". (Clarke S. 1995).

Marxists say that only in communism (socialism) can be equalized the demand for supply because only there is a system where the unique state plan exists, as Lenin has stated: 'This (socialism) is inconceivable without a state organization planned, which keeps tens of millions of people in the strictest respect of a unified standard in production and distribution. 'This means that socialism can be realized and consolidated only when the proletarian state drafts a unified plan for the production and distribution of products to ensure the planned and proportional development of the national economy. (Wu Ching-ŵen 1973).

The countries of Eastern Europe, the USSR, the GDR, Poland, Hungary, Romania, Bulgaria, Yugoslavia, Albania, and Czechoslovakia generally embraced the socialist system. They placed social property beyond the means of production. Their ideological basis was Marxism, with representatives K. Marx and F. Engels. After the 9os, all private property, market economy, and free initiative were established in all these countries.

The leaders of these countries saw that the socialist system was failing, so they try to include elements of the capitalist economy. Thus, for the transition to the market system, the first steps were made before the 1990s. Thus was the theory of "Yugoslav self-government", Russian "Perestroika", "Small farm fields' theory" in Albania, etc. The Socialist system was also embraced in Asian countries like China, Vietnam, North Korea etc, while in the West it was embraced by Cuba.

In the socialist economies that failed, there was also the Albanian economy. The Albanian economy has been the typical socialist system, so we will analyze it in more detail. Until 1990, the 
Albanian economy was socialist. Its features were social property on the means of production, centralized management, lack of market, lack of private property and free initiative. The socialist system survived until 1990. With the protests of 1990, the socialist system changed. The multiparty system was established, which had private property over the means of production, the market economy and the free initiative. In this way, the Albanian economy has experienced both socialist and capitalist systems.

The socialist system in Albania was established in November 1944 after the National Liberation War that the Albanian people made against the invaders, which lead to the forcible overthrow of the capitalist system. In the socialist system, there are socially owned property over the means of production and centralized management, lack of private property, market and free initiative. In this way, the socialist system has radical changes from the capitalist system. There is no market, no demand, and supply, there is no profit, and there is no concept of unemployment and inflation. In socialism there is a one-party system, there is a party-state. In Albania, the Socialist Party (former Labor Party, the former Communist Party) led from 1944 to 1990 . The Socialist state is guided by the Party's Leninist-Marxist policy for strengthening the ever-increasing development of the socialist order. The state takes the lead of the whole society, of economic life, political and social, defense, relations with the rest of the world, etc.

More concretely some of the state's duties in Albania have been the following:

- The management and organization of the people's economy is one of the most important functions of the proletariat's dictatorship

- The state actively acts on production, distribution, exchange, and consumption of social production.

- The state protects common property. It exercises control over labor and consumption.

- The state organizes state leadership with a plan of the economy and folk culture, for the successful implementation of science.

- The state decides with a plan and consciously the proportions between industry and agriculture, production of means of production and consumer goods, aiming to increase the efficiency of social production. (Institute of Economic Studies, Tirana 1973)

The conclusion is; all social-economic life is planned, organized, directed, and controlled by the state from the production stage and so on with distribution, exchange, and consumption. In Socialism, there is Demand and Supply. These two economic categories are not the same insight as in Capitalism. In this system, there is a need on one side and their complement on the other side.

\subsection{Concept of "commodity" in socialism}

In the socialist system cannot be applied the same concepts on the market. There is no market in the socialist economy; there is no Demand, Supply and Market Price. The product is a commodity of a particular type; consequently, demand and supply are of a particular type. 'So our commodity production is not a common commodity product, but a commodity production of a particular type, a non-capitalist commodity production, which is mainly related to the goods of the unified socialist producers (the state, the kolkhoz, the cooperatives)' (Stalin J. 1974). While '...with the society taking the means of production under its control, the production of goods will disappear and with it the dominance of the products over the producers'. (Engels F. 1974). The good (commodity), in the socialist economy, is of a particular type and it is the same concept as in capitalism. In capitalism, the value of use is seen as the bearer of profit. In socialism, the labor's product is directly social; therefore, it is mainly estimated as a value of use.

The "use-value" feature as the first feature is determined by the purpose of socialist production. The goal of socialist production is to produce products only as use-value, as material goods to meet the needs of society". (Political Economy, Socialism 1981)

The value of goods is determined by the amount of social work spent on its production. 
The use-value is the ability of a product to meet a certain human need. In socialism where the purpose of production is to meet the material and cultural needs of society, the value of use is of paramount importance. The value of use is at the center of the attention of state entities. For commodity value, the socialist society is interested in decreasing the production costs continuously. (The value of the goods is identified with the expense expended for its production A.N)

Concrete labor is work that is spent in a certain form. It creates the Usage of Commodity Value.

Abstract labor is the kind of working hours that appears to be a waste of labor in general. It creates the value of goods. (Institute of Economic Studies 1981)

The socially necessary labor time means the average time spent by employees of those specific enterprises that produce the bulk of a particular product.

Individual labor time means work time that is spent by employees of specific enterprises for the production of a particular product. (Institute of Economic Studies 1981)

In socialism, there are no antagonistic contradictions between socially necessary labor and individual work because the socialist economy develops in a planned way. (Institute of Economic Studies.1981)

In the socialist economy, the law of value is not the regulator of the production proportions (I.S.E.1981).

In socialism, the expression of the value law in the field of production is the calculation of the labor's value spent in the form of cost and price. Its action is displayed by comparing the expenses with the results obtained in value. 'Value law does not have a regulatory role in our socialist production, but anyhow it does affect production ...'... the issues that matters are those of "hozrashotit"1 and profitability, the issue of cost, the issue of prices. Therefore, enterprises should not act without taking into account the value law." (Stalin J. 1974).

In the sphere of flow circulation chart, it is expressed in regulating the planning ratios between supply and demand. This is achieved by setting stable prices, fixed for a given time, of unique prices, checking all the other elements that make up the demand and the supply (Institute of Economic Studies 1981). Value law acts in the sphere of circulation. ...' in the exchange of goods through sales, mainly in the exchange of individual consumer goods ... in this sense the value law plays a regulatory role' (Stalin J. 1974)

What can be considered as features of goods production in socialism?

- The production of goods exists in the virtues of the existence of socially owned (state) property.

- The owners of the means of production (people) are also owners of consumer items.

- The purpose of production is based on the fundamental law of socialism, in meeting the ever-increasing cultural-material needs of working masses.

Production ... distribution and consumption are done in a planned manner by the State Plan Committee. This is accomplished through chain balance sheets from the core unit that was the brigade and up to the other scales of economy.

- The production process has a general social character.

- In socialism, are not considered goods and they do not buy-sell factors such as forests, water, rivers, lakes, factories, plants, workforce, etc. When you "sell" products from one enterprise to another they just relocate because the owner is the same, it is society.

The socially necessary labor for goods production, in capitalism, is determined spontaneously, in the market.

The socially necessary labor in socialism is pre-planned, as it starts from the conditions of production objects:

${ }^{1}$ As defined in the Soviet Encyclopedic Dictionary: = khozraschyot is a method of the planned running of an economic unit (i.e., of a business, in Western terms) based on the confrontation of the expenses incurred in production with the production output, on the compensation of expenses with the income. 


\subsection{Price "concept" in socialism.}

In socialism, the price avoids the value to meet the population's demands and needs for certain commodities.

Also in socialism, the government controls and plans all the components of demand and supply. The prices remain constant for certain goods, and they are fixed for long periods.

'Wholesale sale prices and retail sale prices of goods manufactured locally or imported as well... service tariffs, in general, are dictated by the state in a centralized and planned form, which is constrained to be applied by the competent state agencies, establishments, institutions and collectivized agricultural farms (cooperatives)' (Law. No. 7384. 1990).

What criteria did Albania's Government apply in terms of dictating the prices?

- Motivate the increase of industrial and agricultural production in large quantities, variety, and quality to meet up the population demands for mass utilization goods.

- To ensure the price stability and their general fluctuation level ...

- To ensure the continuative increase of mass welfare (workers and farmers), the accomplishment of economic, cultural and social needs for a broad mass spectrum...

- To ensure the necessary socialist accumulation for the continuance of the enlarged reproduction... (Law. No.7384. 1990)

The change of prices is determined by the Council of Ministers and from the designated agencies appointed respectively on its behalf.

The agencies which can determine the prices are the Council of Ministers, the Commission of the State Plan and other central institutions, the Price Byro of the Executive Committees of the People's Councils in the local district, Factories Directories and the Bord of Agricultural Collective Cooperatives. (Law No.7384. 1990)

Which are the "price" concept and its role during the socialist period in Albania?

The price in socialism aimed to measure and express in terms of monetary currency (in a planned methodology), the necessary social labor, which was necessary to produce goods. The "price" concept contributes to the following:

- As an important instrument for the redistribution of the national income;

- Using the "price", the state motivates the increase of the industrial and agricultural products;

- Using the "price", the state incentivizes the quality of the products;

- Price politics serve to encourage and strengthen the economic relationship between rural and urban settlements, as well as industry and agriculture;

- Price is an instrument that harmonizes the purchasing power of the population toward the goods, (demand vs. supply) (Institute of Economic Studies 1981). Look up in the section "demand and supply" are determined from the price in socialism, because the price is set in a centralized planning methodology and it is not self-regulated by the market, as it usually happens in a capitalist market.

\subsection{Demand-Supply concept in socialism and the equilibrium model}

Demand-Supply in socialism is determined by a predefined plan, by the laws in force during the socialist economy, such as the fundamental economic law, the planned proportional development law, the redistribution according to the labor merit law, etc. What does the Fundamental Socialist Law forecast? "To ensure the maximal fulfillment of the increasing basic material and cultural needs of the entire population, throughout the non-stopping growth and constant improvement of the socialist production based on higher industrial technique" (Stalin J. 1974)

In socialism, the sale stores exist, but they are state property. These stores are selling goods in a planned quantity, variety and quality. The price level is not determined by the normal exchange 
between buyers and sellers, but it's pre-planned, unique and fixed for a long time.

In such a way, the demand concept does not represent the real needs of individuals, but instead the dictated needs, imposed by the government. The individual himself is forced to consume those products, in quantity and variety, which are planned to be consumed. He cannot consume more than the planned quantity. In this way, the demand is limited from the amount of money paid to each individual and from the quantity of the products taken in the market to be sold.

The supply represents the quantity and variety of the produced products ready to be sold in the stores. The Supply as well is planned in advance through balance sheets from the production brigades in economical scale. In this way, it is established the quantity of cereals, milk, meat, vegetables, and other products per capita.

The individuals would buy what was offered in the stores and not what they desired. In this way, production was harmonized with consumption, Supply with Demand. They agreed not to have excessive demand and supply in the market, but to have as much commodity as the needs of the people.

Specifically, in this period, The Supply generally speaking convenes with the Demand. What did this convenience imply? This convenience implies that the stores run out of products at the end of the day or during a defined period. The products were sold fast and there was no stock in the production phase. The stores were often empty. They had mostly long term consumption goods. In such a way the tendency for balance between Demand and Supply emptied the market. Such absence of goods in Albania forced the government to distribute the products through vouchers or in other cases via a population nominal list.

DEMAND. The Demand in socialism has a working-class trait. There are two main concepts for the Demand: Demand for a unit, or Demand in kind of goods and Demand in value.

Demand in kind is the quantity of goods that the population needs, taking in consideration their purchase ability, or in other meaning, the Demand in kind is related with different goods which the population need, but also is capable of buying.

Demand in value comprehends the amount of money available to buy good in the retail chain. (Political Economy, Socialism 1981). Demand in value represents the population purchasing power. (Institute of Economic Studies, 1981).

Purchasing power is equal to the demand. It is composed of:

1. The total salaries fond of employees and workers. 2. The collective agricultural cooperatives salaries fond. 3. Social insurances (pensions, temporary disability in working place, etc.) 4. Scholarships and other aid from the state budget 5. Accumulation from the population. 6. Other incomes (interest from saving accounts, incomes from other members of the collective cooperatives, long-term loans and other incomes).

TOTAL AMOUNT of DEMAND $(1+2+3+4+5+6)$, (I.S.E 1981).

The size of the Demand was determined by:

- Volume and structure of Social Production, National Income; the report accumulation fund-consumption fund; the level of income according to population sub-groups; prices levels, population living conditions, habits, their daily routine; the report between urban and rural population; number and composition of the population sorted by age categories; population's levels of education and cultural background; climate conditions and district characteristics (I.S.E 1981);

In determining DEMAND, an important role has held the consumption NORMS per capita of alimentary and non-alimentary goods. These norms were set taking into consideration the quantity of calories, carbohydrates, proteins, population age categories and professional sub-groups, urban and rural differences, district characteristics, etc.

Herein we can detect the differences between determinants of the demand in socialism and capitalism. In capitalism, it is included the income effect, substitution effect, number of buyers, sales and preferences, expectations, population's age structure, season, etc. Everything was planned in socialism. Exactly at this point, we can identify the difference between two systems, the first one is 
very centralized, totally planned and the other one is decentralized, which is complaining to the market conditions.

Socialism's main target is to fulfill the population's needs in quality and quantity, bearing simple products with nice and cheap characteristics.

In socialism, needs are determined as demands of a physiologic and social character that people normally require. Also, they depend on objective and subjective factors, whose key role in realization was played by social factors.

- Characteristics of needs in socialism are; their rapid addition, the fulfillment of the needs of all members of society. The needs are determined by the socialist way of life, meaning that they develop in the interest of revolution and socialism, staying faithful to the communist ideology and morals, etc.

- Even in socialism, there are contradictions between needs and their fulfillment, which often appear as contradictions between production and consumption. The needs are selected in a planned way by increasing the production of certain products on one side, but also by reducing prices and eliminating surplus stock.

- In socialism, there is a division between the "general interest" and "personal interest", where the general interest of the society is predominant and it's placed over the personal interest. The interest is considered to be linked with the concept of well-being.

- Demand is closely related to prosperity. Masses well-being in socialism bears a few characteristics such as it is limited from the development of the socialist society and the opportunity that creates development and economic growth, prosperity is seen as the wellbeing of all the people rather than the individual, in the foreground is the simplicity of the individual.

Which factors are seen as sources of prosperity? The first factor is the increase in the employment rate. The second one is the state planning linked with the level of prices to stimulate the consumption of certain assortments. The third and last factor is the regulation of the salary system, etc.

- In socialism, the relationship between consumption and saving is decided in the form of acting of a law. In this way, in socialism, there is a saving law that acts in conjunction with the basic law, with the law of planned and proportional development of the economy. The key requirement of saving law is saving working time. Its requirements are realized in a conscious and planned manner since the process of designing the production and distribution plan.

- In socialism, there is nominal and real wage. The real salary expresses the amount of consumer items a person buys at nominal wages. In Albania, the reduction of the price level was seen as a way to increase the real wage (Political Economy, Socialism 1981).

SUPPLY. Supply in socialism has a class character. There are two concepts for Supply.

The first concept is in product units, while the second one is in kind and value.

Supply in kind is the amount of commodities that are brought out in the market to be sold to the people. Supply size is determined by two topics; the amount of consumer commodities being produced and secondly from the reserve fund of the society.

Supply in value represents the amount of commodity prices that are available to trade and that can be sold to the population. Supply in value is determined by multiplying the amount of commodities on the market with retail prices. The supply is compiled based on the Balance Sheet of Commodities.

The supply varies depending on the increase in social output and the increase in population requirements. The persistent consistency between DEMAND and SUPPLY is a law of the socialist economy. (Institute of Economic Studies 1981)

The supply is represented by purchasing power coverage.

The distribution of cash in hand goods

1. State Trade, 2. Trade in the collective agricultural cooperatives Noncommercial expenses, 3. 
Services intended for living purposes, 4. Increase of savings deposit accounts, 5. Other noncommercial expenses (tolls of the masses organizations, the payback of the long-term loans, other expenses).

SUPPLY SUM. $(1+2+3+4+5)$ (Institute of Economic Studies 1981)

Demand and Supply in socialism are regulated through the plan and not spontaneously in the market. In Socialism (Demand) that includes; salaries of workers, employees, and villagers' income is regulated by a plan, from a single center (State Plan Commission). Supply is also planned through the quantity and types of products for the market, through services intended to the population, through the determination of selling prices (State Plan Commission).

From the above analysis, we can construct a linkage scheme from the production until distribution, fulfilling the Basic Law of Socialism, for a typical socialist economy such as the Albanian economy, has been.

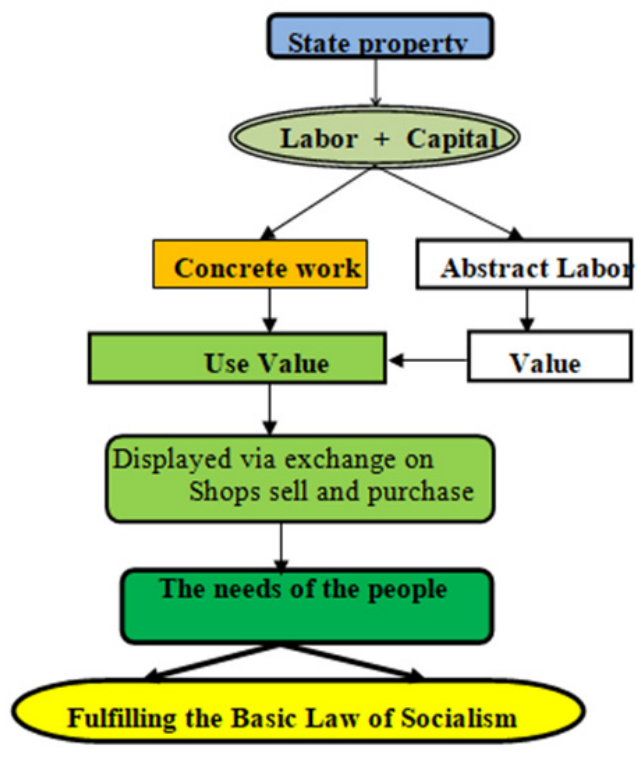

Fig. No.4: The Way of creating Demand-Supply in the Socialist System.

Source: Author

Starting from the concepts of demand-supply in the socialist system and the scheme of production purpose in socialism, we can build the sales scheme in socialism.

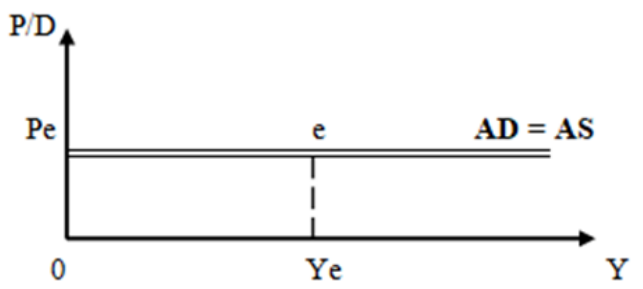

Fig. No. 5: "Market" Structure in Socialism

Source: Author 
In the above scheme, the aggregate price is set at Y-axis, while the Y-output quantity is set on the Xaxis. Demand Curve $=$ Needs $=$ D equals Stock of goods $=$ Supply $=S$ at point E (Equilibrium). In this scheme, any increase or decrease in price and output is done by the plan. The equilibrium point is defined. The price trend in socialism is growing fast. This trend is accompanied by rising nominal salaries and, consequently, real wages. In this way, the overall demand and supply curve also has a slight upward slope.

\section{Combining the Curves of the Two Systems. Chinese Economy}

\subsection{Chinese economy, mix-economy, the socialism of the market economy}

The Chinese model has been objective in assessing the situation of its economy. They have consistently aimed at realizing material balances in line with the needs of the people, aiming at mitigating and eliminating the poverty rate, increasing the degree of employment, wellbeing, welfare, equal development of different provinces and eradicating inequality. Their achievements are supported by the experience of the country, the experience of other countries, and the development of science, relying both on state-owned property and private property, socialism and capitalism. This goal is expressed in the features of Chinese socialism based on the market economy. In this way, no specific market model can be built for the Chinese economy, as is the case of a market model that can be built for the Albanian economy.

China is a typical example of a compound or mix economy. In this economy, there are elements of centralized governance, as well as elements of the market economy. In China, socialism coexists with capitalism, under the label of the Chinese socialism of the market economy. This Chinese socialism of the market economy did not immediately arise. It started with the creation of the Communist Party of China (CPC), with the views of Mao Zedong. He has gone through unexplained paths and unexamined experiments in any other economy in the world.

China is based on its economic and political heritage, appreciating every philosophical thought from Confucius, Sun Jat Seni followed by Mao Zedong, Deng Xiaoping, and Xi Jinping.

Mao in 1938 said: "Today's China is the product of all of China's past development. We cannot put aside our historical past. We have to do the generalization of all of our past from Confucius to Sun Jat Seni ... If the Communists treat Marxism by taking it away from China's features, this will be an abstract and unobtrusive Marxism. Therefore, we must apply Marxism in the concrete conditions of China so that in all its manifestations it necessarily reflects specific Chinese characteristics ... "(Mao Ce Dun 1963).

\subsection{Planning system up to '8os}

The planning apparatus in the early 1950 s was modeled on the centralized Soviet system. This system depended on a central planning unit that computed and balanced the quantities of the main offered and requested goods. Until the 1980s, the economy was managed and coordinated through economic plans formulated at all levels of administration. Some of the theses cast by Chinese leaders over the years have been:

Zhou Enlai said in 1944: "China is not yet a communist country and if Mao Zedong's policy is to be fairly implemented, it will not become a communist country for a long time (International Herald Tribune 14.8.1978).

In 1945 Mao said: "Under the leadership of our party we must fight ... to build a new, bright, independent, free, democratic, united, rich and powerful China" (Mao Ce Dun 1963).

'Some think Chinese communists are opposed to the development of private initiative, they are against the development of private capital, against the protection of private property. Indeed it is not so ... to ensure that the vast circles of the Chinese have the opportunity to freely develop the private initiative in society, to freely develop the private capitalist economy, to ensure the protection of all 
privately acquired property legitimate. "(Mao Ce Dun 1963).

In 1950, Mao said 'We have created a political, economic and organizational front along with the national bourgeoisie.' (Mao Ce Dun, 1967). "In the past, we have followed this policy of mobilizing all positive factors to end the rule of imperialism, feudalism and bureaucratic capitalism so to achieve victory for the democratic revolution of the people. We are now following the same policy to continue the socialist revolution and build a socialist country." (Mao Ce Dun 1956). Thus, the changes of the 198 os did not come spontaneously, but they were in the course of the progressive thinking of the time, in the positive attitude towards private property and the market economy.

Until the 1980s, most good prices were settled by government agencies and rarely changed ... In 1987 the price structure in China was chaotic. Some awards were set in the market through supply and demand forces, others were deployed by government agencies, and others were produced by procedures that were not clearly defined. (Wikipedia)

During 1953-1980, the Chinese planning system faced the same problems of instability and reaction as in the other centrally planned economies. The underlying difficulty has been the difficulty of forecasting all the needs of the economy and determining the exact features of the factors and the products planned. Beginning in 1979 and 1980, the first reforms were presented on an experimental basis.

\subsection{Planning system after '8os}

Communist Party authorities began economic reforms by introducing market principles in 1978 . Starting from this year, the Chinese government gradually began to enter its economy into the market economy, allowing individual enterprises to produce and compete with state-owned enterprises. The amendments were sanctioned in the 1982 Constitution and were significantly improved in the 2004 constitution.

Reforms would take place in two phases: The first phase, in the late 1970s and early 1980s, included de-collectivization of agriculture, the opening of the country toward the foreign investment, allowing entrepreneurs to start businesses. However, most of the industry remained state-owned. The second phase of the reform, in the late 1980 os and 1990s, included privatization and contracting from many state industries and the abolition of price control, protectionist policies and regulations, although state monopolies in sectors such as banks and oil remained. The private sector grew much, accounting for up to 70 percent of China's gross domestic product in 2005. (Wikipedia)

During this period, China's development was supported by the ideological leaders of the CPC. Deng Xiaoping and Xi Jinping. They turned into promoters of Chinese socialism initiatives with features of the market economy. At the 14th National Congress of China, Deng said: 'A planned economy is not the definition of socialism, because there is also planning under capitalism; the market economy is under socialism. Planning and market forces are two ways to control economic activity "(Xiaoping D 1984). He introduced new concepts into Chinese economic thinking such as "socialism with Chinese characteristics" and "the primary stage of socialism", Marxism does not look as a dogma for action, but applicable in terms of the Chinese economy.

At the 19th National Congress of China, it was emphasized: '... we will give the market forces a decisive role in the distribution of resources and we will ensure that the government plays its role better; to advance structural supply reform; to create a socialist ruling system with Chinese characteristics; to advance the broad development...', “... that socialism with Chinese characteristics has entered into a new era and the main contradictions in Chinese society have evolved between unbalanced and inadequate development and the ever-growing needs of people for life good." (Xinhua Oct. 24, 2017).

The conclusion of the achievements in the Chinese economy is based on two transformations "Over the past three decades, China's two historical transformations, from a rural, agricultural society into an urban and industrial economy. The second transformation is the change from a centralized economy into a market-based economy. Both transformations have combined to give spectacular 
results.”(China 2030. 23 march 2013)

\subsection{What are some features of today's Chinese economy and some differences from the US economy?}

The Chinese economy is a mixed economy, which means that, first, there is state property and state economic planning; secondly, there are private properties with the operation of market economy laws. Through the economic planning, the Chinese government is not involved in any area; it focuses mainly on the direction of production of individual industrial sectors and regions, key branches of strategic importance, reform of market institutions, policies of an open door economy, in achieving welfare and social stability.

For Chinese economic thought, planning reflects the Chinese tradition of Chinese society's collectivity. It presupposes the government and popular thinking agreement, in pursuit of certain objectives, in the common interest of society. The planning process in the Chinese economy follows almost the same path that follows or has pursued in the former socialist countries, from bottom-up project plans and top-down plans. Under the direction of the Party, the way of planning is; Central government-government at the provincial-city-district-country level. In this way, the material balance sheet is compiled. The main governing bodies of the planning process have changed constantly. In 2006, the National Commission for Development and Reform (NCDR) was renamed 'with the term of neglected planning to convey to the world that China was no longer a centrally planned economy' (Chou C.G 2011). The National People's Congress approves each plan.

If we put the features of a typical capitalist economy like the USA, in front of the Chinese economy we would have these differences:

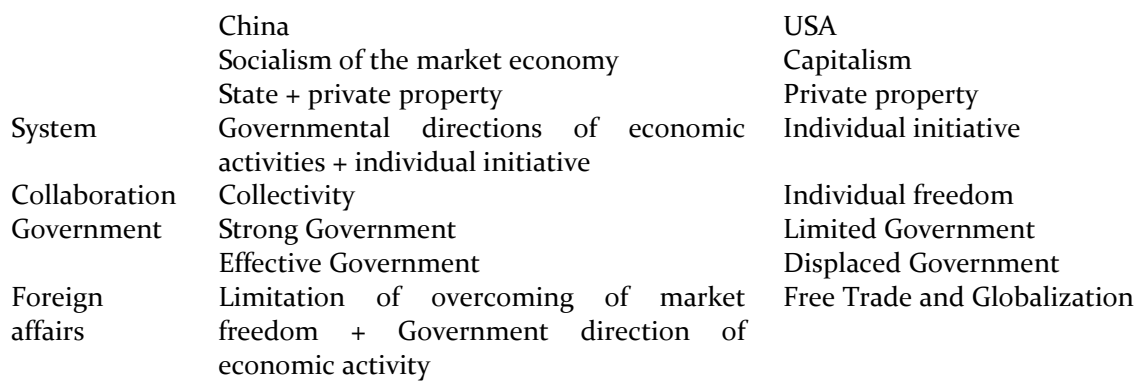

These are some of the main differences between the two economies; mixed economy and market economy.

Many Chinese economists have expressed their thoughts about market equilibrium. We are mentioning the evaluations of one of them.

'The planned economy is only possible in socialism' ... 'Anarchy in social production is replaced by the planned organization and it is organized' ... Social production is aimed at meeting the evergrowing needs of the entire society, in the interest of all people who work, instead of nurturing the private interests of the few '...' Under a unified state plan, it can distribute the labor force and means of production to the various departments of the national economy to use rationally the human, material and financial resources to enlighten the needs of the state and people."(Wu Ching-ŵen 1973)

Mao Zedong regarding the market equilibrium emphasized '... while production forces develop, the old balance is often outdated and results in a new imbalance ...' Balance is nothing more than a temporary relative union of opposites. By the end of each year, this balance, taken as a whole, is outdated by the struggle of opposites; unity is subject to change, the balance falls into imbalance, unity becomes a disruption, and again it is necessary to create a balance and unity for the coming 
year. 'Because the battle of opposites is absolute, the imbalance is a frequent phenomenon'. ( $\hat{W u}$ Ching-ŵen 1973). Based on the transition stages of the Chinese economy, we can build an aggregate market model;
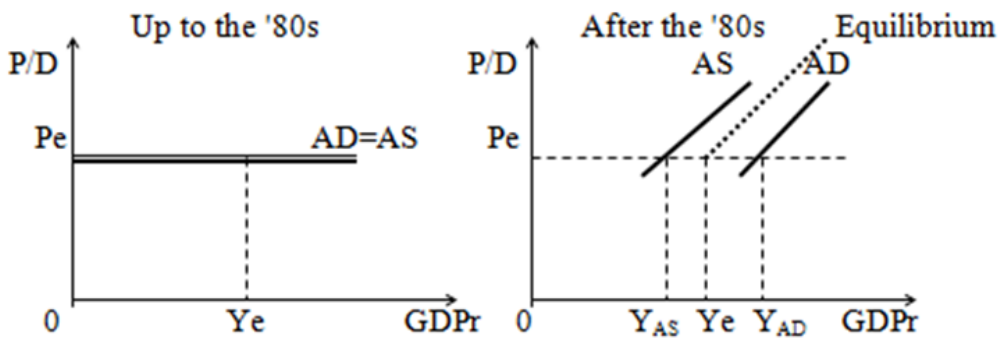

Fig. No. 6: Chinese aggregate market

Source: Author

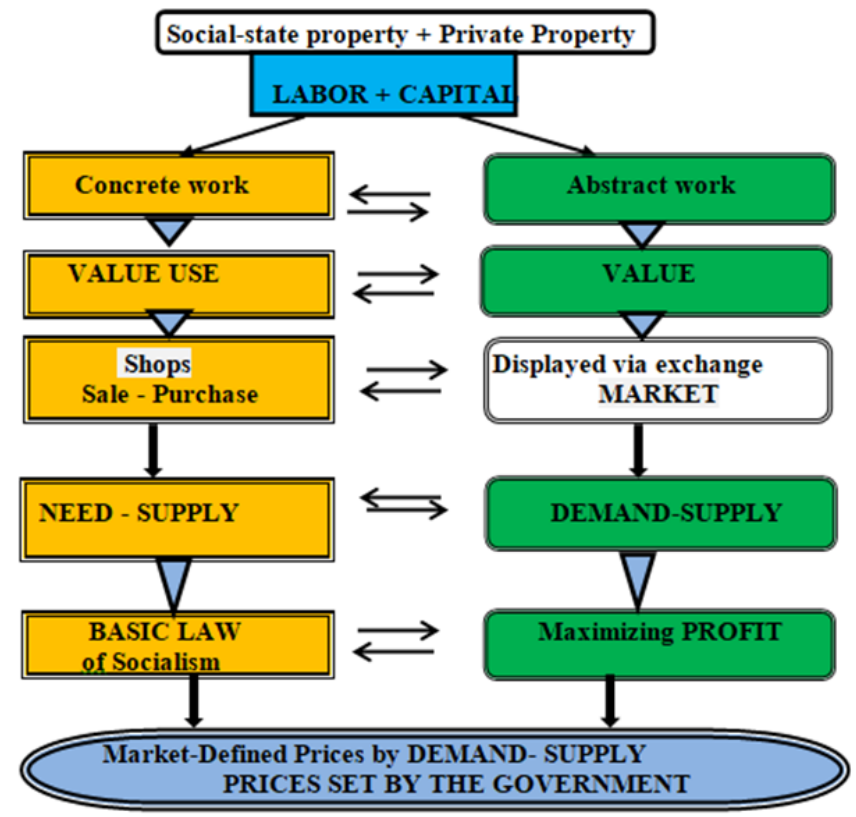

Fig. No.7: Supply - Demand creation scheme in a mixed economy

Source: Author

\section{Applying the Market Economy Model to the Albanian Economy}

The Aggregate Market Model has been applied to the Albanian economy data, assuming Aggregate Demand, Internal Demand, and Aggregate Supply, Added Value. As the equilibrium curve forms from the demand-supply interaction, the Gross Domestic Product (GDP) curve was realized. This indicator includes monetary, fiscal, foreign relations policies, and so on.

Through this model, anyone can analyze the factors and components of the above Indicators. Below we are illustrating a new model with data from the Albanian economy 


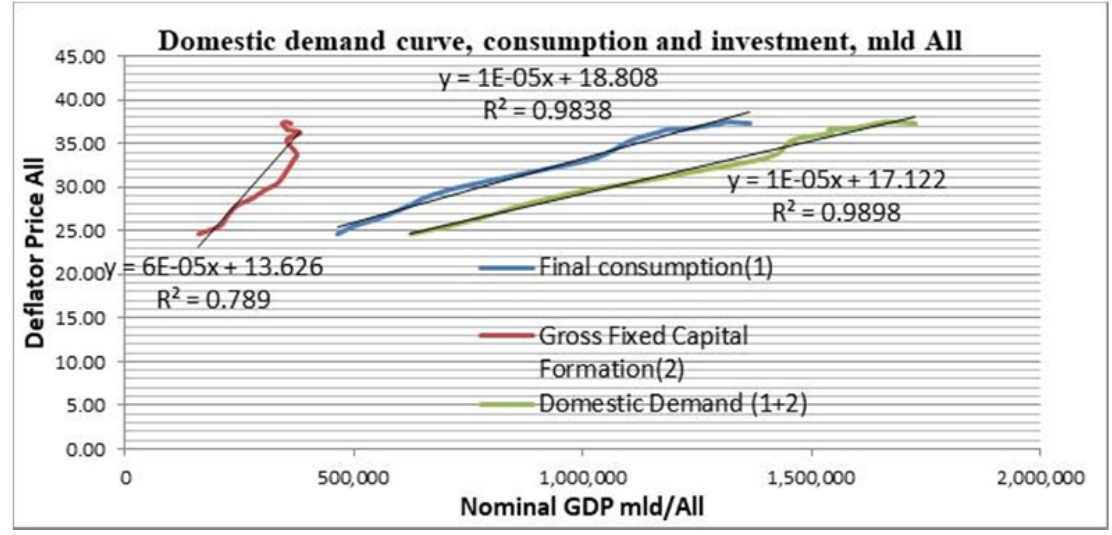

Fig. No.8: Internal Demand Structure in the Albanian Economy (2000-2016) (Naqellari A.2018) Source: Author

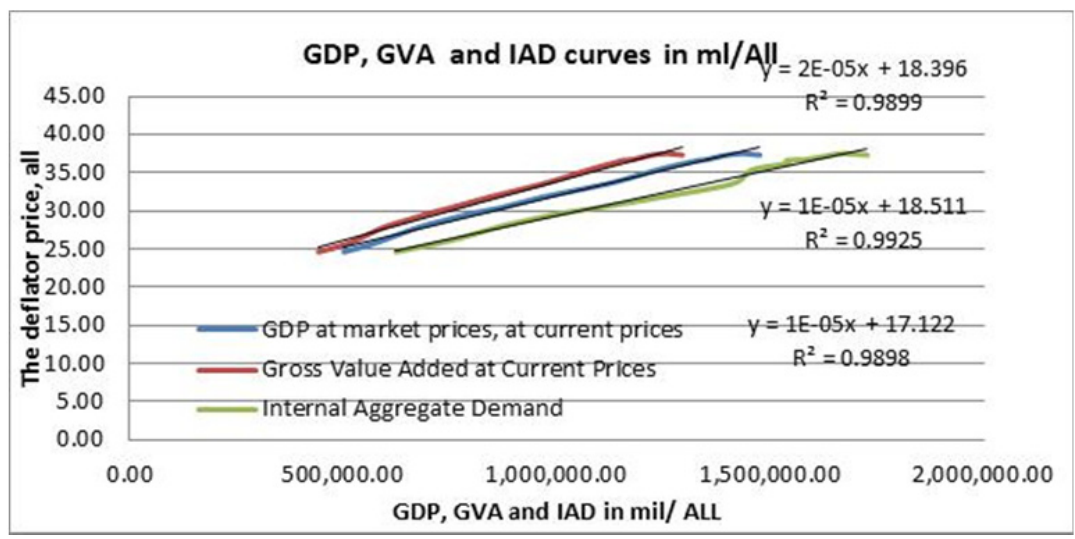

Fig. No.9: The new model of the aggregate market built with data from the Albanian economy (200o2016) (Naqellari A. 2018)

Source: Author

The above new models are built with data from the Albanian economy. Through this model can be drawn the curve of nominal GDP and real GDP. The impact of price increases and real GDP growth can be analyzed. The curve regime can be analyzed by the change of real and nominal GDP. Curve responses bring a novelty to the theoretical sphere because, in general, do not match the curve reactions in the Keynesian model used so far. That is why we recommend this model as real, as true and not just theoretical.

\section{Conclusions}

Marxist theory has analyzed important concepts of the economy such as property, labor, rent, goods, market, demand, supply, etc. The goods were carefully analyzed and through it all related concepts such as concrete work, abstract work, value, usage value, turnover, demand, and supply. Some of these concepts have been identified in the paper and the aim is to highlight the relationship between supply and demand. The relationships between them are viewed by analyzing their commodities and 
features. Here is reflected the link between ownership over the means of production, production, commodities, labor form that contains the commodity and the value that it creates to the market. There is clear evidence of market equilibrium, demand mismatches with supply to the capitalist system and the role of price in this equilibrium. It is evidenced by the production estimation through revenues and expenditures and the role of prices. The supply price equated to the value of the goods as a whole is seen as a form of production valuation rather than as a match between demand and supply, as a balance. Matching according to them does not happen in this system where there are antagonistic contradictions between private and social labor, concrete and abstract work but occurs in the socialist system. Exactly in the socialist system, the goods are viewed in a different kind, of a different kind, as is the market. Socialism is not a goal of profit but complementing the needs of the masses through balancing the demand with the supply. While in the capital system the engine of production is profit. In socialism, concrete labor is reflected in the demand-supply, while in capitalism the abstract labor is reflected in the production and profit of the enterprises. A connection to socialism and capitalism has been realized according to the Marxist theory between ownership, production of goods and its emergence in the market. A market model scheme in socialism has been implemented, where the demand and supply position is defined. The mixed Chinese economy was analyzed and relevant market models were built. An aggregate market model scheme with data from the Albanian economy has been implemented.

\section{Recommendations}

We recommend to the Albanian Government, the Central Bank, state institutions, and all public and private institutions in their analysis of the Gross Domestic Product indicators to apply the Model of Market Scheme that we have implemented. The proposed New Model is real and applicable in every economy. Through its realistic analyzes, real-world data, and conclusions can be drawn in the interest of economic development.

We recommend the Universities to put this new model alongside the Classic and Keynesian model as an applicable model in the economy rather than theoretical. Applying this model will give the opportunity to field scholars to create other concepts on the factors that affect the growth of the economy, affecting the rate of inflation and unemployment.

\section{References}

Beijing, Oct. 24 (Xinhua) -- Resolution of the 19th National Congress of the Communist Party of China on the Report of the 18th Central Committee. October 24, 2017. Source: Xinhua| 2017-10-24 16:22:10| Editor: Yamei

China 2030. Building a Modern, Harmonious, and Creative Society. The Word Bank Development Research Center of the State Council, the People's Republic of China. 2013. UPDATE - Final edition of the report as published on March 23, 2013

Engels F. 1974. Anti Dyring, Publishing House November 8th. Tirana

Gregory C. Chô̂ 2011. Economic Planning in China by Gregory C. Chow, Princeton University CEPS Working Paper No. 219 June 2011.

Institute of Economic Studies. 1973. People's Republic of Albania. Problems of the organization and direction of the popular economy in the P. R. A. Printing House November 8, Tirana.

Institute of Economic Studies 1981. People's Republic of Albania. Knowledge of socialist economy. Publishing House November 8th, Tirana 1981.

Karl Marks. Marxism. 1975. Publishing House November 8. Tirana

Law No. 7581, dated 7.07.1992. On prices and fees.- Official Journal 4, August 1992, p.187; 11 articles. Law No. 7384 , dated 8.5.1990 "On prices and tariffs" is repealed.

Lenin I.V. 1970. Works, Volume 36, Publishing House November 8th. Tirana 1970.

Mao Tse Tung. On the Ten Major Relationships. Selected Works of Mao Tse-tung. April $25,1956$. https://www.marxists.org/reference/archive/mao/selected-works/volume-5/mswv5_51.htm

Mao Ce Dun. Selected works. Volume 1, Volume 2, Volume 3, Publishing House November 8th. Tirana 1963.

Mao Tse Toung, “Oeuvres choisies” . Edition en langues etrangeres. Pekin 1967. 
International Herald Tribune 14.8.1978. https://www.google.com/search?q=\%E2\%8o\%A2+ International+Herald+Tribune+14.8.1978...

Marx K. On Criticism of Political Economy. Publishing House 8 November. Tirana 1977.

Marx K, The Misery of Philosophy. Reply to Mr. Prudon's "Philosophy of Misery". Reprint. Publishing House "8 November" Tirana, 1978.

Marx K.1968. Capital, Volume One, Book 1. Publishing House November 8th. Tirana 1968.

Marks K \& Engels F. 1958. Selected works in two volumes. Volume I.OGIZ Moscow Political Literature Publishing House 1948. Party History Institute at K.Q.1958. Print in the German Democratic Republic at the VEB Offizin Andersen Nexo Printing House, Leipzig.

Naqellari A. 2018. Positive Slope Model of Aggregate Demand. Mediterranean University of Albania. Academic Jour nal of Interdisciplinary Studies. Volume 7: Issue 3. November 2018.

Political Economy (Capitalism) 1985. Reprint of the 1980 edition. Publishing House November 8th. Tirana 1985. R.P.S.SH. Academy of Sciences. Institute of Economic Studies.

Political Economy (Socialism). 1981. R.P.S.SH. Academy Of Sciences. Institute of Economic Studies. Publishing House November 8th. Tirana.

Simon Clarke. "Marx and the Market", Centre for Social Theory, University of California, Los Angeles, April 1995. http://homepages.warwick.ac.uk/ syrbe/pubs/LAMARKW.pdf

Stalin V.J.1974. The Economic Problems of Socialism in the USSR, Stalin V.J.1974. Publishing House November 8th. Tirana

Xiaoping, Deng (1 October 1984). "Building Socialism with a Specifically Chinese Character". People's Daily. Archived from the original on 3 July 2018. Retrieved 3 July 2018

Wu Ching-ŵwen 1973. Socialist Planned Economy- Notes on studying political economyby Wu Ching wen. This article is reprinted from Peking Revieŵ, \#11, March 16, 1973. 